\title{
Biological variation of serum insulin concentrations in healthy cats
}

\author{
Emma Strage $e^{1,2}$ \\ From Animal Obesity - causes, consequences and comparative aspects \\ Uppsala, Sweden. 14-16 June 2015
}

\section{Introduction}

The prevalence of diabetes mellitus (DM) in cats is increasing. It has been proposed that fasting concentrations of insulin and glucose can be used for screening of reduced insulin sensitivity in cats. Reduced insulin sensitivity may indicate that cats are at risk of developing DM and motivate early preventive actions such as weight reduction and change of diet. To correctly interpret results it is important to know the biological variation of insulin i.e. the normal variation of insulin between and within cats. For glucose, coefficient of variation (CV) for between and within cats is reported to be 8.1 and $6.8 \%$, respectively, but until now there are no data of biological variation of insulin in cats.

\section{Objectives}

To determine biological variation of insulin in healthy cats.

\section{Methods}

Healthy cats $(n=5)$ were sampled in their home environment once a week for 5 weeks. Blood samples were drawn from the cephalic vein in the morning after $>12$ hour fast. Insulin was measured in duplicate by the previously validated Mercodia feline insulin ELISA. Nested analysis of variance was used for statistical calculations.

\section{Results}

Insulin ranged from 71.8-304.5 (median 127.3) $\mathrm{ng} / \mathrm{L}$. CV between and within cats was $58.0 \%$ and $34.1 \%$, respectively.

\footnotetext{
Correspondence: emma.strage@slu.se

'Department of Clinical Sciences, Swedish University of Agricultural Sciences, Uppsala, Sweden

Full list of author information is available at the end of the article
}

\section{Conclusions}

Biological variation of insulin within a cat is considerably higher than previously published results for glucose. This needs to be taken into account when interpreting insulin concentrations.

\section{Authors' details}

${ }^{1}$ Department of Clinical Sciences, Swedish University of Agricultural Sciences, Uppsala, Sweden. ${ }^{2}$ Clinical Pathology Laboratory, University Animal Hospital, Swedish University of Agricultural Sciences, Uppsala, Sweden.

Published: 25 September 2015

doi:10.1186/1751-0147-57-S1-014

Cite this article as: Strage: Biological variation of serum insulin concentrations in healthy cats. Acta Veterinaria Scandinavica 2015 57(Suppl 1):014.
Submit your next manuscript to BioMed Central and take full advantage of:

- Convenient online submission

- Thorough peer review

- No space constraints or color figure charges

- Immediate publication on acceptance

- Inclusion in PubMed, CAS, Scopus and Google Scholar

- Research which is freely available for redistribution
C Biomed Central 